Research Article

\title{
Adversity and emotional quotients of public elementary school heads amidst the COVID-19
}

\author{
Edward Castro Jimenez \\ Schools Division of City of Meycauayan, Philippines
}

\begin{abstract}
This study aimed to identify the relationship of adversity quotient and emotional quotient amongst public elementary school heads. The study employed a descriptive-correlation research design with the online survey as primary data collection tool. The respondents came from the 25 elementary schools in a Schools Division Office in Central Luzon. 25 elementary school heads participated in the online survey using universal sampling technique. Adapted questionnaires were used to gather data. For the statistical treatment of the study, mean was used for the responses of the school heads; for the relationship, the study used Pearson-r. This paper concluded that the school heads' Adversity Quotient (AQ) score falls within "above average," which indicates above normal capacity for challenges, difficulties, setbacks, and demands. In terms of emotional quotient, all factors involved in emotional intelligence like self-awareness, managing emotions, motivating oneself, empathy, and social skill all "apply" to school heads. In addition, there exists a significant relationship between adversity quotient and emotional quotient of public elementary school heads. Based on the aforementioned results, the researcher provided some important recommendations for the study.
\end{abstract}

Keywords: Adversity quotient, emotional quotient, school heads, public schools, COVID-19 pandemic

\section{Introduction}

Adversity quotient and emotional quotient are two important qualities that should be cultivated by a person nowadays. The advent of rapid change brought about by the pandemic and the emotional maturity it requires call for rapid adjustment and resiliency. The events connected to this global health issue forced people to adjust their routines as the pandemic limited movement to avoid contact and prevent the spread of the Novel Corona Virus Disease (COVID-19). Asio (2021) once mentioned that prior to the pandemic, school personnel were productive. The massive damages of COVID-19 may be incalculable, but in the spirit of taking opportunities as they present themselves, this event presents a prospect of rethinking education. The change in direction should not be about improving schooling, but should focus on the what, how, and where of learning (Zhao, 2020).

Education setup all over the world has changed to lessen the vulnerability of children and the teachers, the persons mostly involved in the physical setting. Therefore, it is essential to find a suitable approach that focuses on delivering strategic instruction to the 21 st century learners (Sebastian, 2019). Although a study found out that public schools were not yet ready for distance learning (Asio \& Bayucca, 2021), the process must go on. The Department of Education, in response, modified its practices and processes to continue serving the learners and purposely accomplish its mandate. Considering the fact that teachers have high emotional quotient (Jimenez, 2020), different learning modalities were offered to cater to the various needs of the

\section{Address of Corresponding Author}

Edward Castro Jimenez, PhD, Schools Division of City of Meycauayan, Demaprtment of Education, Bulacan, Philippines.

edward.jimenez@deped.gov.ph

0000-0001-6876-7935

How to cite: Jimenez, E. C. (2021). Adversity and emotional quotients of public elementary school heads amidst the COVID-19. International Journal of Didactical Studies, 2(2), 101460. https://doi.org/10.33902/IJODS.2021269755 
learners to where they are comfortable and available to continue their education even while at home. Educating learners is the core reason for all teaching-learning processes which is undertaken in each classroom whether formal or informal platform (Asio \& Jimenez, 2020). Online learning, printed learning, blended learning, and radio-based instruction learning modalities were the options presented by DepEd to continue its teaching-learning process among schools. The change in the curriculum and the type of learning delivery require all the School Heads (SHs) to take note of the level of their Adversity Quotient (AQ) and Emotional Quotient (EQ) to better understand these adjustments and provide a better working condition for their staff.

Education leaders, especially the SHs find it difficult to adjust with the latest modalities of management and supervision of teachers. Leaders took unprecedented social distancing measures to protect the health and well-being of citizens (Bailey \& Schurz, 2020). Positive thinking, in conjunction with a robust attitude, can affect one's well-being and coping strategies under stressful events (Relojo et al., 2015). In a study by Asio (2019), students have moderate understanding about teacher bullying. And this time of pandemic, bullying a teacher is also a possibility. The call for adjusting with the new normal stretched the wisdom of the government in terms of administering health measures, and with that, the SHs' plans in normal schooling were scrapped for a special implementation strategy. The suspension of face-to-face classes became a dilemma to everyone, where all were required to adjust to the offerings of different learning modalities. The call for the new learning schemes, as expected for the initial stages of a new plan, created confusion to all especially to parents because of their unpreparedness and setbacks to education while tending to their needs amid the pandemic. The threat grew larger, and it created unprecedented anxieties amongst everyone.

At present, SHs are still on the process of coping with the new normal of education. Teachers are left with the uncertainties with the teaching and learning process amid the pandemic (Jimenez, 2021). The coping mechanisms like attending mental health awareness webinars, tending to their psycho-social attributes and the like are some measures given to the teachers to get along with the new normal and new trends in education. Continuous participation to various activities of the government and private entities concerning flexible learning options, to leadership webinars under the New Normal, and to managerial perspectives of leaders under crisis are encouraged among SHs to continue becoming the catalysts of change in the workplace and in society in general. It proves that the organizational climate affects teachers to a great extent (Asio, 2020).

Having considered all these, the researcher has crafted this study with the aim of giving light on the relationship of adversity quotient and emotional quotient of elementary School Heads. This paper is limited to the SHs of the Schools Division of Office in Central Luzon for the school year 2020-2021. This research will also be used in formulating management programs and interventions of school leaders in addressing their teachers' mental health and stress levels in developing learning resources.

\subsection{Literature Review}

\subsubsection{Adversity quotient}

Adversity Quotient is a person's response to overcoming obstacles or problems (Juwita, 2020). According to Suryadi and Santoso (2017) in their study entitled "Self-Efficacy, Adversity Quotient, and Students' Achievement in Mathematics," there are significant effects of self-efficacy on the adversity quotient, but no significant effects of gender on students' academic mathematics achievements. This implies that further investigation on how to improve students' self-efficacy and adversity quotient in mathematics is encouraged.

In the study conducted by Puspitacandri et al. (2020) entitled "The Effects of Intelligence, Emotional, Spiritual and Adversity Quotient on the Graduates Quality in Surabaya Shipping Polytechnic," they pointed out that there are direct and indirect effects of adversity quotient on the graduates quality, meaning that each quotient has a positive effect on a graduate's value and wellbeing. The quality of learners is based on the increase of academic performance in their class that the use of electronic tools provided by the teachers create a sound learning environment to master the different learning competencies (Jimenez, 2020).

Moreover, in the study of adversity quotient of the grade three elementary students particularly on the semiotic reasoning in constructing properties of a rectangle conducted by Suryaningrum et al. (2020), where they used signs to represent a mathematical concept in a problem-solving ability, they classified three levels of Adversity Quotients: (1) quitter/AQ low; (2) champer/AQ medium; and (3) climber/AQ high. Results show that three participants identify objects by 
observing the things around them. The quitter found two characteristics of rectangular objects then derived them to be a rectangle's properties. The champer found four characteristics of the objects then derived them to be two properties of a rectangle. Meanwhile, climber found six characteristics of the sign and derived all of these to be four properties of a rectangle. Generally, climber could determine the properties of a rectangle correctly.

There are no significant differences in the level of Adversity Quotient (AQ) and Defense Mechanism (DM) amongst boys and girls, according to the research of Nikam \& Uplane (2013). Their study, conducted to secondary school students on the relationship of their AQ and DM, revealed that there is no correlation between $A Q$ and DM based from the samples taken from 156 girls and 152 boys aged 13 to 15 years that were randomly selected.

In the same manner, a study conducted by Sunan (2015) on the influences of moral, emotional and adversity quotient on good citizenship stressed out that adversity quotient and moral quotient has a positive direct effect on good relationship based on the 0.01 level of significance, while emotional quotient has a negative direct effect on good citizenship with the significance level of 0.05 .

\subsubsection{Emotional quotient}

Positive thinking, in conjunction with a robust attitude, can affect one's well-being and coping strategies under stressful events. It stresses the role of Emotional Quotient to everybody (Relojo et al., 2015). In the event of a teacher's burnout, there is a need to conduct Emotional and Intelligence Quotient assessments to better identify underlying factors that solicit safeguarding of mental and emotional distress of teachers. According to Hammett (2013) in her study entitled "Examining Teacher Burnout Using Emotional Intelligence Quotients: A Correlational Study," there was a significant relationship between demographic characteristics and the constructs of both the emotional intelligence survey and the burnout inventory. Quantitative data analysis also showed that that there were no significant differences between the constructs of burnout and the constructs of emotional intelligence, and the demographic variables.

Meanwhile, the study conducted by Kucukkaragoz (2020) entitled "Family Environment and Emotional Quotient in Primary School $3^{\text {rd }}$ Grade Students" with 167 students as respondents, posited that EQ levels of $3^{\text {rd }}$ grade students vary significantly as to family income, mother's/father's profession, mother's and father's educational level, household size and preschool experience. This means that there are significant differences according to family income levels, mothers' professions and education levels, fathers' professions and education levels, the number of members of the students' families, and whether students continue their pre-school education.

In a similar study by Maqbool (2019) about emotional intelligence and online English language of 122 distance education graduate learners on their academic achievement, it was revealed that there is a significant relationship between emotional intelligence and the level of ESL learners' achievement at graduate level. As manifested by the various research studies conducted, the level of emotional intelligence of student-teachers in terms of emotional literacy, emotional quotient competencies and emotional quotient on values and attitudes registered vulnerable results and their level of mathematic competence were deemed satisfactory (Eustaquio, 2015).

According to Demirtas (2010) in his study entitled "The Relationship between Principal's Emotional Intelligence Quotient, School Culture, and Student Achievement," a principal's emotional intelligence quotient was not significantly associated with school culture, and negatively associated with student achievement. Furthermore, the combination of predictor variables, principal's emotional intelligence quotient and school culture did not significantly predict student achievement.

From a study by Riego de Dios (2020) regarding the emotional intelligence and work values of selected instructors from a tertiary education institution, the author stated that respondents have moderate emotional intelligence. At the same time the respondents agreed that work values are important in their career.

This study gained related insights and perspective as to how school heads should manage their work-related activities as well as management of different resources which entail resilience, tenacity, responsibility, accountability, action, energy, and perseverance. The related studies presented would give all school leaders and managers to address the necessities in the school management and utilization of school resources (both human and non-human) properly. The relationship between $\mathrm{AQ}$ and EQ amongst school leaders and teachers provide greater understanding to provide quality management of schools and better teaching practices among teachers. This may result to better communication channels, learning opportunities, and positive 
atmosphere among members of the organization with positive outlook and psycho-social attributes which are present to all.

\section{Method}

\subsection{Research Design}

This study used a quantitative research design, particularly the descriptive-correlational research method. According to Driessnack et al. (2007), quantitative research is the most often research method used to quantify relationship between or among variables - the independent or predictor variable/s and the dependent or outcome variable/s. Since the main concern of the study is to identify the relationship between the adversity quotient and the emotional quotient of elementary school heads, the mentioned design and method fits.

\subsection{Respondents of the Study}

The participants of this study were the 25 elementary school heads in the Schools Division Office in Central Luzon for the school year 2020-2021 which also covers the period of the Corona Virus Disease (COVID) pandemic. Universal sampling technique was used by the researcher in the conduct of the study. The 25 elementary school heads in the Schools Division of Office in Central Luzon were selected as the respondents of the study. The total population size was used as the actual sample size population of respondents. According to Avron et al. (2019), reconstructing continuous signals based on a small number of discrete samples is a fundamental problem across science and engineering.

\subsection{Instrument of the Study}

The researcher adopted questionnaires for this study, namely, the Adversity Quotient Profile developed by Stolz and Grant (2019) and the Emotional Intelligence (EI) created by Goleman and Gurin (1995). The former is a 20-survey questionnaire that assesses the AQ of the respondents as to which indicator they belonged: Core, Ownership, Reach, and Endurance (Stolz \& Grant, 2019), while the latter is another adopted instrument used to identify the Emotional Intelligence of the respondents which includes Self-Awareness, Managing Emotions, Motivating Oneself, Empathy, and Social Skill (Goleman \& Gurin, 1995).

\subsection{Data Analysis}

The result of this study was tabulated and treated using MS Excel and SPSS version 22. A frequency count of the responses was treated fairly. This research employed the Pearson correlation analysis to best describe the relationship between adversity quotient and emotional quotient of the elementary school heads. Meanwhile, a five-point Likert scales were used to describe the status of school heads' adversity and emotional quotients. For adversity quotient, the descriptive interpretations were 1-not at all, 2-somewhat, 3-partially, 4-moderately, and 5completely. And for emotional quotient, the following descriptive interpretations were 1-does not apply, 2-applies a little, 3-moderately applies, 4-applies, and 5-always applies. The following intervals were used to interpret the data: $1.00-1.49=$ Not at all; $1.50-2.49=$ Somewhat; $2.50-3.49=$ Partially; 3.50-4.49= Moderately; 4.50-5.00= Completely.

\section{Results and Discussion}

The study dealt with the correlation of adversity quotient and emotional quotient of elementary school heads to increase their awareness, agility, endurance, and emotional levels in handling changes in the workplace, particularly in the Schools Division Office in Central Luzon.

Table 1

Adversity Quotient of School Heads in terms of Control

\begin{tabular}{lcc}
\hline Control & Mean & Interpretation \\
\hline $\begin{array}{l}\text { 1. You suffer a major financial setback. To what extent can you influence this } \\
\text { situation? }\end{array}$ & 3.54 & Moderately \\
$\begin{array}{l}\text { 2. People respond unfavorably to your latest ideas that you feel can get you } \\
\text { past a crisis. To what extent can you influence this situation? }\end{array}$ & 3.50 & Moderately \\
$\begin{array}{l}\text { 3. Your personal and work obligations are out of balance. To what extent can } \\
\text { you influence this situation? }\end{array}$ & 4.04 \\
$\begin{array}{l}\text { 4. You are not exercising regularly though you know you should. To what } \\
\text { extent can you influence this situation? }\end{array}$ & 3.85 \\
$\begin{array}{l}\text { 5. Your computer crashed for the third time this week. To what extent can } \\
\text { you influence this situation? }\end{array}$ & 3.69 & Moderately \\
\hline Average Mean & 3.72 & Moderately \\
\hline
\end{tabular}


Table 1 presents the evaluation of the school heads with regard to their adversity quotient in terms of control. As can be seen from the table, item number 3, "Your personal and work obligations are out of balance. To what extent can you influence this situation?" was rated the highest with an average mean of 4.04, while item number 5, "Your computer crashed for the third time this week. To what extent can you influence this situation?" was rated the lowest with an average mean of 3.69. The overall average mean was computed at 3.69 which was verbally interpreted as "Moderately," as shown in Table 1. This means that the extent which school heads perceive they can influence whatever happens next.

Table 2

Adversity Quotient of School Heads in terms of Ownership

\begin{tabular}{lcc}
\hline Ownership & Mean & Interpretation \\
\hline $\begin{array}{l}\text { 1. You are overlooked for a promotion. To what extent do you feel } \\
\text { responsible for improving the situation? }\end{array}$ & 3.65 & $\begin{array}{c}\text { Moderately } \\
\text { Responsible }\end{array}$ \\
$\begin{array}{l}\text { 2. Someone you respect ignores your attempt to discuss an important } \\
\text { issue. To what extent do you feel responsible for improving this } \\
\text { situation? }\end{array}$ & 3.65 & $\begin{array}{c}\text { Moderately } \\
\text { Responsible }\end{array}$ \\
$\begin{array}{l}\text { 3. Your workplace is understaffed. To what extent do you feel } \\
\text { responsible for improving this situation? }\end{array}$ & 4.31 & $\begin{array}{c}\text { Moderately } \\
\text { Responsible } \\
\text { 4. Your organization is not meeting its goals. To what extent do you } \\
\text { feel responsible for improving this situation? }\end{array}$ \\
$\begin{array}{l}\text { 5. The meeting you are in is a total waste of time. To what extent do } \\
\text { you feel responsible for improving this situation? }\end{array}$ & 4.27 & $\begin{array}{c}\text { Moderately } \\
\text { Responsible } \\
\text { Avederately }\end{array}$ \\
\hline Average Mean & 3.54 & $\begin{array}{c}\text { Moderately } \\
\text { Responsible }\end{array}$ \\
\hline
\end{tabular}

Table 2 presents the evaluation of school heads with regard to their adversity quotient in terms of ownership. As shown in the table, item statement number 3, "Your workplace is understaffed. To what extent do you feel responsible for improving this situation?" was rated the highest with an average mean of 4.31 while item statement number 5 , "The meeting you are in is a total waste of time. To what extent do you feel responsible for improving this situation?" was rated as the lowest with an average mean of 3.54. The overall average mean was computed at 3.88 with a verbal interpretation of "Moderately Responsible". It implies the likelihood that school heads will actually do anything to improve the situation, regardless of their formal responsibilities.

Table 3

Adversity Quotient of School Heads in terms of Reach

Reach

The consequences of this situation will:

2 . The high-priority project you are working on gets canceled.

The consequences of this situation will:

3. You hit every red light on your way to an important

appointment. The consequences of this situation will:

3.88 Somewhat affect all

4. You miss an important appointment. The consequences of this situation will:

5 . Your boss (or client) adamantly disagrees with your decision. The consequences will:

aspects of my life

3.69 Somewhat affect all aspects of my life
Partially affect all aspects of my life

3.65 Somewhat affect all aspects of my life

3.77 Somewhat affect all aspects of my life

Average Mean

3.68 Somewhat affect all aspects of my life

Table 3 presents the evaluation of school heads with regard to their adversity quotient in terms of reach. As can be seen from the table, item number 1, "You are criticized for a big project that you just completed. The consequences of this situation will:" was rated as the highest with an average mean of 3.88 , while item number 3 , "You hit every red light on your way to an important appointment. The consequences of this situation will:" was rated as the lowest with a computed mean of 3.42. The overall average mean was tabulated at 3.68 and verbally interpreted as "Somewhat affect all aspects of my life" as shown in Table 3. Results indicate the extent to which school heads perceive an adversity will "reach into" and affect other aspects of the situation or beyond. 
Table 4

Adversity Quotient of School Heads in terms of Endurance

\begin{tabular}{|c|c|c|}
\hline Endurance & Mean & Interpretation \\
\hline $\begin{array}{l}\text { 1. You accidentally delete an important email. The consequences of } \\
\text { this situation will: }\end{array}$ & 3.65 & $\begin{array}{l}\text { Moderately } \\
\text { Forever }\end{array}$ \\
\hline $\begin{array}{l}\text { 2. You are unable to take a much-needed vacation. The consequences } \\
\text { of this situation will: }\end{array}$ & 4.08 & $\begin{array}{l}\text { Moderately } \\
\text { Forever }\end{array}$ \\
\hline $\begin{array}{l}\text { 3. After extensive searching, you cannot find a critical document. The } \\
\text { consequences of this situation will: }\end{array}$ & 3.42 & $\begin{array}{l}\text { Partially } \\
\text { Forever }\end{array}$ \\
\hline $\begin{array}{l}\text { 4. You never seem to have enough money. The consequences of this } \\
\text { situation will: }\end{array}$ & 4.08 & $\begin{array}{l}\text { Moderately } \\
\text { Forever }\end{array}$ \\
\hline $\begin{array}{l}\text { 5. You lost something that is very important. The consequences of this } \\
\text { situation will: }\end{array}$ & 3.35 & $\begin{array}{l}\text { Partially } \\
\text { Forever }\end{array}$ \\
\hline Average Mean & 3.72 & $\begin{array}{l}\text { Moderately } \\
\text { Forever }\end{array}$ \\
\hline
\end{tabular}

Table 4 shows the evaluation of school heads as regards their adversity quotient in terms of endurance. As can be seen from the table, specifically item statements number 2 and 4, "You are unable to take a much-needed vacation. The consequences of this situation will:" and "You never seem to have enough money. The consequences of this situation will:" were rated the highest with an average mean of 4.08, while item statement number 5, "You lost something that is very important. The consequences of this situation will:" was rated as the lowest with an average mean of 3.35. The overall average mean was computed at 3.72 with a verbal interpretation of "Moderately Forever". The results imply that the length of time the school heads perceive the situation/adversity in the organization will last or endure.

The overall score of the respondents with 149.6 computed value falls within "above average". This simply means that school heads have above normal capacity in handling challenges, difficulties, setbacks, and demands at work and in personal attributes. This is strengthened by the study conducted by Fauziah et al. (2020) which showed that learning model and adversity quotient have an influence on divergent-thinking skills.

Table 5

Emotional Quotient of School Heads in terms of Self-Awareness

\begin{tabular}{lcc}
\hline Self-Awareness & Mean & Interpretation \\
\hline 1. I realize immediately when I lose my temper. & 3.88 & Applies \\
2. I know when I am happy. & 4.62 & Always Applies \\
3. I usually recognize when I am stressed. & 4.15 & Applies \\
4. When I am being emotional" I am aware of this. & 4.46 & Applies \\
5. When I feel anxious, I usually can account the reason/s. & 4.19 & Applies \\
6. I always know when I'm being unreasonable. & 4.00 & Applies \\
7. Awareness of my own emotions is very important to me at all times. & 4.35 & Applies \\
8. I can tell if someone has upset or annoyed me. & 4.12 & Applies \\
9. I can let anger "go" quickly so that it no longer affects me. & 4.12 & Applies \\
10. I know what makes me happy. & 4.69 & Always Applies \\
\hline Average Mean & 4.26 & Applies \\
\hline
\end{tabular}

Table 5 shows the emotional quotient of school heads in terms of their self-awareness. As can be seen from the table, item number 10, "I know what makes me happy." was rated as the highest with a weighted mean of 4.69 , while item number 1 , "I realize immediately when I lose my temper." was rated as the lowest with a computed mean of 3.88. The overall average mean was computed at 4.26 with a verbal interpretation of "Applies". This simply means that school heads apply the ability to recognize what they are feeling, to understand their habitual emotional responses to events and to recognize how their emotions affect their behavior and performance. 
Table 6

Emotional Quotient of School Heads in terms of Managing Emotions

\begin{tabular}{lcc}
\hline Managing Emotions & Mean & Interpretation \\
\hline 1. I can "reframe" bad situations quickly. & 4.00 & Applies \\
2. I do not wear my "hear on my sleeve". & 3.50 & Applies \\
3. Others can rarely tell what kind of mood I am in. & 3.77 & Applies \\
4. I rarely "flu off the handle" at other people. & 3.46 & Moderately \\
5. Difficult people do not annoy me. & 3.81 & Applies \\
6. I can consciously alter my frame of mind or mood. & 4.15 & Applies \\
7. I do not let stressful situations or people affect me once I have left & 4.12 & Applies \\
work. & 3.73 & Applies \\
8. I rarely worry about work or life in general. & 4.23 & Applies \\
9. I can surpass my emotions when I need to. & 3.85 & Applies \\
10. Others often do not know I am feeling about things. & 3.86 & Applies \\
\hline Average Mean & &
\end{tabular}

Table 6 poses the evaluation of the school heads in their emotional quotient in terms of managing emotions. The table shows that item number 9, "I can surpass my emotions when I need to." was rated as the highest with an average mean of 4.23 , while the lowest item statement was item number 4, "I rarely "flu off the handle" at other people." with an average mean of 3.46, which had a verbal interpretation of "Applies." The overall average mean was tabulated at 3.86 and verbally interpreted as "Applies" as shown in Table 6. This implies that the ability to stay focused and think clearly even when experience powerful emotions are being managed by the school heads.

Table 7

Emotional Quotient of School Heads in terms of Motivating Oneself

\begin{tabular}{lcc}
\hline Motivating Oneself & Mean & Interpretation \\
\hline 1. I am able to always motive myself to do difficult tasks. & 4.27 & Applies \\
2. I am usually able to prioritize important activities at work and get & 4.50 & Always Applies \\
on with them. & 4.00 & Applies \\
3. I always meet deadlines. & 4.23 & Applies \\
4. I never waste time. & 4.15 & Applies \\
5. I do not prevaricate (deviate from truth). & 4.23 & Applies \\
6. I believe you should do the difficult things first. & 3.77 & Applies \\
7. Delayed gratification is a virtue that I hold onto. & 4.31 & Applies \\
8. I believe in "Action this Day". & 4.31 & Applies \\
9. I can always motivate myself even when I feel low. & 4.50 & Always Applies \\
10. Motivations has been the key to my success. & 4.23 & Applies \\
\hline Average Mean & & \\
\hline
\end{tabular}

Table 7 reveals the highest and lowest ranking of the emotional quotient of school heads in terms of motivating oneself. Item numbers 2 and 10, "I am usually able to prioritize important activities at work and get on with them." and "Motivations has been the key to my success." ranked first with a computed mean of 4.50 , while item number 7 , "Delayed gratification is a virtue that I hold onto." was rated the lowest with a computed average mean of 3.77. The overall average mean was computed at 4.23 which was verbally interpreted as "Applies". The results suggest that the school heads' ability to use their deepest emotions to move and guide them toward their goals are being applied in life.

Table 8 presents the evaluation of the school heads regarding their emotional quotient in terms of empathy. Table shows that item number 9, "I can sometimes see things from others' point of view." was rated the highest with a computed mean of 4.46 , while item number 8 , "I can understand why my actions sometimes offend others." was rated the lowest with a computed weighted mean of 3.77. As can be seen in Table 8, all item statements were tabulated and had an overall weighted mean of 4.12 and were verbally interpreted as "Applies". It is postulated that the ability of school heads to sense, understand, and respond to what other people are feeling are manifested in their daily lives. 
Table 8

Emotional Quotient of School Heads in terms of Empathy

\begin{tabular}{lcc}
\hline Empathy & Mean & Interpretation \\
\hline 1. I am always able to see things from the other person's viewpoint. & 4.12 & Applies \\
2. I am excellent at empathizing with someone else's problem. & 4.23 & Applies \\
3. I can tell if someone is not happy with me. & 4.00 & Applies \\
4. I can tell if a team of people are not getting along with each other. & 4.15 & Applies \\
5. I can usually understand why people are being difficult towards me. & 3.85 & Applies \\
6. Other individuals are not "difficult" just "different". & 4.35 & Applies \\
7. I can understand if I am being unreasonable. & 4.19 & Applies \\
8. I can understand why my actions sometimes offend others. & 3.77 & Applies \\
9. I can sometimes see things from others' point of view. & 4.46 & Applies \\
10. Reasons for disagreements are always clear to me. & 4.19 & Applies \\
\hline Average Mean & 4.12 & Applies \\
\hline
\end{tabular}

Table 9

Emotional Quotient of School Heads in terms of Social Skill

\begin{tabular}{lcc}
\hline Social Skill & Mean & Interpretation \\
\hline 1. I am an excellent listener. & 4.27 & Applies \\
2. I never interrupt other people's conversations. & 4.38 & Applies \\
3. I am good at adapting and mixing with a variety of people. & 4.15 & Applies \\
4. People are the most interesting thing in life for me. & 4.08 & Applies \\
5. I love to meet new people and get to know what makes them "tick". & 3.85 & Applies \\
6. I need a variety of work colleagues to make my job interesting. & 4.00 & Applies \\
7. I like to ask questions to find out what it is important to people. & 4.04 & Applies \\
8. I see working with difficult people as simply a challenge to win them & 3.88 & Applies \\
over. & 4.27 & Applies \\
9. I am good at reconciling differences with other people. & 4.54 & Always Applies \\
10. I generally build solid relationships with those I work with. & 4.15 & Applies \\
\hline Average Mean & & \\
\hline
\end{tabular}

Table 9 shows the emotional quotient of school heads in terms of their social skill. As can be glimpsed from the table, item number 10, "I generally build solid relationships with those I work with." was rated the highest with a weighted mean of 4.54 , while item number 8 , "I see working with difficult people as simply a challenge to win them over." was rated the lowest with a computed mean of 3.88. The overall average mean was computed at 4.15 with a verbal interpretation of "Applies". The results reveal that the school heads ability to manage, influence, and inspire emotions in others are essential foundation skills for successful teamwork and leadership.

Table 10

Correlation between Adversity Quotient and Emotional Quotient of the Respondents

\begin{tabular}{llcc}
\hline & & AQ & EQ \\
\hline Adversity Quotient & Pearson-r & 1 & $.620^{*}$ \\
& Sig. (2-tailed) & & .001 \\
& $\mathrm{~N}$ & 26 & 26 \\
Emotional Quotient & $.620^{*}$ & 1 \\
& Pearson-r & .001 & 26 \\
& Sig. (2-tailed) & 26 & 26 \\
\hline
\end{tabular}

* $p<.05$

Table 10 shows the relationship between adversity quotient and emotional quotient of public elementary SHs. It can be gleaned that adversity quotient has a significant relationship with the emotional quotient. This is because the adversity quotient obtained a Pearson Correlation of .001, which is lower than the alpha significance level of .01.

According to Bautista et al. (2016) the relationship between adversity quotient and leadership style is significant. Likewise, the relationship of emotional health and learning resource development fosters significant impacts (Jimenez, 2021a). Result of the research conducted proves the significant relationship of adversity quotient and emotional quotient among public elementary school heads. This is similar to the study conducted by Hulaikah et al. (2020) which 
emphasized the interactions between experiential learning and adversity quotients that improved students problem solving ability. This also poses for interventions to SHs for the changing world of schools to adapt and become change modifiers that will cater to the needs of the learners and teachers (Jimenez, 2021b).

\section{Conclusion}

Based on the results of the study, the researcher concluded that (1) the school heads' adversity quotient scores fall within above average level which indicates above normal capacity for challenges, difficulties, setbacks, and demands; (2) the school heads' emotional quotient scores fall above the average level also which shows above normal capability for self-awareness, managing emotions, motivating oneself, empathy, and social skills; and (3) there is a strong evidence of relationship between adversity and emotional quotient.

\section{Recommendations}

In the light of the conclusions drawn, the following recommendations are hereby offered by the researcher:

a. school heads should perceive resiliency, healthy and tenacity in the workplace to influence what happens next;

b. school heads, as prime movers of leadership and management, should always try to do their best in improving every situation regardless of their formal responsibilities. Promotion of increased human resource engagement is encouraged;

c. school heads should sustain characteristics like tolerating gestures and adaptability structure to eradicate the chance of cumulative effect of burden, stress, energy, and effort;

d. school heads should develop and harness coping mechanisms that could provide hopeful, optimistic, and willing atmosphere that will help personnel to perceive that the situation/adversity will pass;

e. school heads should preserve to invoke sensitivity to understand habitual emotional responses to events and recognize how emotions affect teaching performance and nonteaching behavior and performance;

f. school heads should attend wellness programs that should be done regularly to enhance focus-based mentality and constructively transform emotional setbacks and obstacles into motivations that may challenge their leadership skills in managing resources;

g. school heads should exemplify good governance and housekeeping particularly accountability and transparency in utilizing government's funds and resources;

h. Schools Division Offices should establish school heads' service center (SHSC) that would provide psychosocial assistance and emotional health awareness; and

i. Schools Division Officials may use this study as springboard in the development of their programs, projects, and activities to adapt this strategy for the improvement of school leadership and management amongst schools to better serve its clientele.

\section{References}

Asio, J.M.R. (2021). Determinants of work productivity among selected tertiary education employees: A preCOVID-19 pandemic analysis. International Journal of Didactical Studies, 2(1), 101455. https://doi.org/10.33902/IJODS.2021167470

Asio, J.M.R., \& Bayucca, S.A. (2021). Spearheading education during the COVID-19 rife: Administrators' level of digital competence and schools' readiness on distance learning. Journal of Pedagogical Sociology and Psychology, 3(1), 19-26. https://doi.org/10.33902/JPSP.2021364728

Asio, J.M.R. (2020). Effect of performance review and faculty development to organizational climate. International Journal of Management, Technology and Social Sciences, 5(2), 1-10. http://doi.org/10.5281/zenodo.3976934

Asio, J.M.R. (2019). Students bullying teachers: Understanding and behavior of college students from a higher education institution. Journal of Pedagogical Research 3(2), 11-20. http://dx.doi.org/10.33902/JPR.2019254157

Asio, J. M. R., \& Jimenez, E. C. (2020). Effect of remediation activities on grade 5 pupils' academic performance in technology and livelihood education (TLE). Pedagogical Research, 5(4), em0075. https://doi.org/10.29333/pr/8464

Bailey, B. J. P., \& Schurz, J. (2020). COVID-19 is creating a school personnel crisis. American Enterprise Institute, May, 1-11. https://www.aei.org/research-products/report/covid-19-is- 
creating-a-school-personnel-crisis /

Bautista, R. L. V., Pascua, M. G. D., Tiu, J. V., \& Vela, C. D. (2016). Adversity Quotient and Leadership Styles amongs Students Leaders in Bulacan (Unpublished Master's Thesis). Bulacan State University, Phillippines.

Demirtas, Z. (2010). The Relationship between School Culture and Student Achievement. Egitim ve Bilim-Education and Science, 35(158), 3-13.

Eustaquio, W. R. (2015). Student-teachers in higher education institutions' (HEIS) emotional intelligence and mathematical competencies. Journal of Education and Practice, 6(13), 76-78.

Fauziah, M., Marmoah, S., Murwaningsih, T., \& Saddhono, K. (2020). The effect of thinking actively in a social context and creative problem-solving learning models on divergent-thinking skills viewed from adversity quotient. European Journal of Educational Research, 9(2), 537-568. https://doi.org/10.12973/eu-jer.9.2.537

Goleman, D. \& Gurin, J. (1995). (Eds.) Mind body medicine: How to use your mind for better health. Consumer Reports Books.

Hammett, J. (2013). Tesis - Examining Teacher Burnout Using Emotional Intelligence Quotients: a Correlational Study. Tesis, 53(9), 1689-1699.

Hulaikah, M., Degeng, I. N. S., Sulton, \& Murwani, F. D. (2020). The effect of experiential learning and adversity quotient on problem solving ability. International Journal of Instruction, 13(1), 869-884. https://doi.org/10.29333/iji.2020.13156a

Jimenez, E. C. (2020). Contextualized e-learning resource: A tool for stronger academic platform. International Journal of Case Studies in Business, IT, and Education. 4(2), 110-116.

Jimenez, E. C. (2021). Project New Normal (navigating electronic world to numerous online resources of modality approaches in learning. International Journal of Multidisciplinary: Applied Business and Education Research 2(1), 134 - 140. https://doi.org/10.11594/ijmaber.02.01.09

Jimenez, E. C. (2020). Emotional quotient, work attitude and teaching performance of secondary school teachers. Journal of Pedagogical Sociology and Psychology, 2(1), 25-35. https://doi.org/10.33902/jpsp.2020161079

Jimenez, E. C.. (2021). Impact of Mental Health and Stress Level of Teachers to Learning Resource Development. Shanlax International Journal of Education, 9(2), 1-11.

Kucukkaragoz, H. (2020). Family environment and emotional quotient in primary school 3rd grade students. Cypriot Journal of Educational Sciences, 15(2), 336-348. https://doi.org/10.18844/cjes.v15i2.4805

Maqbool, S. (2019). Emotional intelligence and online English language learners' academic achievement. Pakistan Journal of Distance and Online Learning, 5(n1), 91-104.

Nikam, V. B., \& Uplane, M. M. (2013). Adversity Quotient and Defense Mechanism of Secondary School Students. Universal Journal of Educational Research, 1(4), 303-308.

Puspitacandri, A., Warsono, Soesatyo, Y., Roesminingsih, E., \& Susanto, H. (2020). The effects of intelligence, emotional, spiritual and adversity quotient on the graduates quality in surabaya shipping polytechnic. European Journal of Educational Research, 9(3), 1075-1087. https://doi.org/10.12973/EU-JER.9.3.1075

Relojo, D., Pilao, S. J., \& Rosa, R. Dela. (2015). From Passion to emotion: Emotional quotient as predictor of work attitude behaviour among faculty members. I-Manager's Journal on Educational Psychology, 8(4), 1-10. https://doi.org/10.26634/jpsy.8.4.3266

Stolz, P. G. \& Grant, B. (2019). Grant consulting: Informing change, peak learning report (AQ profile 10.0, 2019 technical report). https://www.peaklearning.com/wpcontent/uploads/2019/04/PEAK_AQP_technicalSupplement .$p d f$

Sunan, S. (2015). Influences of moral, emotional and adversity quotient on good citizenship of Rajabhat Universitys Students in the Northeast of Thailand. Educational Research and Reviews, 10(17), 2413-2421. https://doi.org/10.5897/err2015.2212

Suryadi, B., \& Santoso, T. I. (2017). Self-Efficacy, Adversity Quotient, and Students' Achievement in Mathematics. International Education Studies, $10(10), \quad 12$. https://doi.org/10.5539/ies.v10n10p12

Suryaningrum, C. W., Purwanto, Subanji, Susanto, H., Ningtyas, Y. D. W. K., \& Irfan, M. (2020). Semiotic reasoning emerges in constructing properties of a rectangle: A study of adversity quotient. Journal on Mathematics Education, 11(1), 95-110. https://doi.org/10.22342/jme.11.1.9766.95-110

Zhao, Y. (2020). COVID-19 as a catalyst for educational change. Prospects, 49(1-2), 29-33. https://doi.org/10.1007/s11125-020-09477-y 